\title{
Selective Membrane Sensor for Aluminum Determination in Food Products, Real Samples and Standard Alloys
}

\author{
Sabry Khalil * and Ashraf Y. Elnaggar
}

Citation: Khalil, S.; Elnaggar, A.Y. Selective Membrane Sensor for Aluminum Determination in Food Products, Real Samples and Standard Alloys. Membranes 2021, 11, 504. https://doi.org/10.3390/ membranes 11070504

Academic Editor: Andrzej Lewenstam

Received: 30 May 2021

Accepted: 11 June 2021

Published: 30 June 2021

Publisher's Note: MDPI stays neutral with regard to jurisdictional claims in published maps and institutional affiliations.

Copyright: (c) 2021 by the authors. Licensee MDPI, Basel, Switzerland. This article is an open access article distributed under the terms and conditions of the Creative Commons Attribution (CC BY) license (https:/ / creativecommons.org/licenses/by/ $4.0 /)$.
Department of Food Nutrition Science, College of Science, Taif University, P.O. Box 11099, Taif 21944, Saudi Arabia; aynaggar@Tu.edu.sa

* Correspondence: Sabry@Tu.edu.sa

\begin{abstract}
The study involves the fabrication of an aluminum liquid membrane sensor based on the association of aluminum ions with the cited reagent 2,9-dimethyl-4,11-diphenyl -1,5,8,12-tetraaza cyclote tradeca-1,4,8,11-tetraene [DDTCT]. The characteristics slope (58 mV), rapid and linear response for aluminum ion was displayed by the proposed sensor within the concentration range $2.5 \times 10^{-7}-1.5 \times 10^{-1} \mathrm{M}$, the detection limit $\left(1.6 \times 10^{-7}\right) \mathrm{M}$, the selectivity behavior toward some metal cations, the response time $10 \mathrm{~s}$ ), lifetime (150 days), the effect of $\mathrm{pH}$ on the suggested electrode potential and the requisite analytical validations were examined. The suitable $\mathrm{pH}$ range was (5.0-8.0), in this range the proposed electrode response is independent of $\mathrm{pH}$. The suggested electrode was applied to detect the aluminum ions concentration in food products, real samples and standard alloys. The resulting data by the suggested electrode were statistically analyzed, and compared with the previously reported aluminum ion-selective electrodes in the literature.
\end{abstract}

Keywords: ion-associate Tetraaza Tetraene complexes; membrane sensor; aluminum estimation; food; real samples; alloys analysis

\section{Introduction}

Aluminum can be found in combination with other elements, and cannot be excreted by patients with kidney failure diseases. In the dialysis fluid or the long-time medical treatment toxicity associated with exposure to aluminum is now recognized [1]. Care is taken to check blood levels of aluminum in patients with kidney failure. Aluminum can cause toxicity in humans, and is also a valuable factor in pathological diseases [2-6]. Thus, it is very significant to estimate aluminum in pharmaceuticals, real samples, alloys and food stuff.

Utilities of electrode sensors have developed to use in different ways [7-9]. Many techniques, like, atomic absorption spectrometry; AAS [10-16], spectro-fluorometry [17,18], chromatography [19-22], a laser diode atomic absorption spectroscopy [23], inductively coupled plasma-atomic emission spectrometry; ICP-AES [24-26], inductively coupled plasma-mass spectra; ICP/MS [27-30], spectrophotometry based on use of various reagents [31-41], ion-selective electrode techniques [42-52] and other recently different methods [53-63] have been listed for the estimation of aluminum. Although those reported methods are highly sensitive for the determination of aluminum ions, some difficult complications were produced in their applications. Voltammetry is a very ponderous procedure in spite of it is economic. Potentiometric estimation based on the ion-selective membrane electrode is very simple and introduced several good characteristics, like wide linearity in the concentration range, easy sampling, rapid response, simple equipment, highly selective with a very low value of detection limit, carried out in turbid, colored, and/or viscous solutions and less cost. Anyway, many of the previously reported electrodes suffering from interfering in calcium ions and have a limited range of concentration. 
New reagents from heterodiazo dyes which form very stable and strong ion-associates with some active ions of some metals were designed to determine them in pharmaceutical and food products by new, very sensitive, and selective spectrophotometric detection $[64,65]$.

The reagent 2,9-dimethyl-4,11-diphenyl-1,5,8,12-tetra azacyclotetra deca-1,4,8,11-tetraene [DDTCT] contains the functional groups tetradeca, and tetraene have attracted considerable attention as a synthetic ionophore, as this armed macrocycle, as a result of its structural characteristics, binds metal cations with different strengths, and thus, can be convenient as electro active material to apply in selective sensor. This compound has been utilized for the estimation of a numerous metal cations [66]. Therefore, we decided to use it in the designation of a new aluminum electrode.

The present work describes the construction and evaluation of aluminum(III) membrane sensor. The active constituents in a polyvinyl chloride; (PVC) matrix selective sensors are the $\mathrm{Al}^{3+}$ with the cited reagent [DDTCT] ion associate complex. The characteristics slope, linear and rapid response for aluminum ion was presented by the developed ionselective electrode within the concentration range $2.5 \times 10^{-7}-1.5 \times 10^{-1} \mathrm{M}$, the limit of detection limit $\left(1.6 \times 10^{-7}\right) \mathrm{M}$, the selectivity behavior toward some metal cations, the lifetime (150 days), the response time (10 s), the influence of $\mathrm{pH}$ on the sensor potential and the interesting analytical parameters were examined. The suitable $\mathrm{pH}$ range was (5.0-8.0); the response of the proposed electrode is not affected by $\mathrm{pH}$ change in this range. The sensor is successfully utilized for the estimation of the concentration of aluminum (III) ions in food products, real samples and standard alloys.

The produced data by the suggested electrode were analyzed, and compared with those of various published aluminum ion-selective electrodes.

\section{Chemicals and Methods}

\subsection{Product Samples, Chemicals and Reagents}

Aluminum, cadmium, sodium, zinc, nickel, cobalt, and calcium chlorides, ammonium and sodium hydroxide, hydrogen peroxide and polyvinyl chloride; PVC were Aldrich products. Hydrochloric, hydrofluoric and sulfuric acids, tetrahydrofuran, TBP(tributylphosphate), acetate buffer solution and methanol from Merck Germany. Food products containing aluminum (Bread, Flour, Rice, Tea-Leaves, Tomato Sauce and Chocolate) were purchased from the local stores and markets in Saudi Arabia and Egypt, real samples (Granite, Basalt, Rhyolite), and standard alloys (Copper-based alloy NBS164 and Zinc-based alloy NIST94C).

\subsection{Preparation of Stock Solutions}

Chloride stock solutions of aluminum, zinc, nickel, cadmium, sodium, cobalt, and calcium of 0.1 molar solution were weighed and dissolving the calculated quantities of each one in distilled $\mathrm{H}_{2} \mathrm{O} .10^{-7}-10^{-1}$ molar solutions were conditioned by dilution.

Standard solutions of aluminum chloride utilized in the estimation of aluminum in, food products, real and standard alloys samples were weighed, a calculated quantity of each sample was prepared in 0.01 molar sodium chloride and conditioned by dilution.

\subsection{Sampling for Aluminum Ions Determination}

The prerequisite solutions for potentiometric measurements were obtained as follows: a content of food products (Bread, Flour, Rice, Tea-Leaves, Tomato Sauce, and Chocolate) were selected for analysis. For the analysis of $\mathrm{Al}^{3+}$ ions in bread and chocolate, samples were cut, washed, then heated at $120^{\circ} \mathrm{C}$ for $2 \mathrm{~h}$. Weight strictly 10 grams, transferred (460 and $400 \mathrm{mg}$ of them, respectively) into a crucible, heated at $600{ }^{\circ} \mathrm{C}$ for $4 \mathrm{~h}$. for ashing, after entiring the ashing the samples were cooled to the ambient temperature, $5 \mathrm{~mL}$ of diluted $\mathrm{HCl}$ were added for dissolving the resulting residues, put into a $50 \mathrm{~mL}$ calibrated marked flask and diluted with distilled $\mathrm{H}_{2} \mathrm{O}$. For flour and rice, 10-grams sample was accurately weighed, transferred (750 and $1500 \mathrm{mg}$, respectively) to a quartz crucible. $10 \mathrm{~mL}$ concentrated nitric acid was added, evaporated to dryness. By heating concentrated $\mathrm{H}_{2} \mathrm{O}_{2}$ was added gradually till a clear solution is obtained, then evaporated. To eliminate $\mathrm{H}_{2} \mathrm{O}_{2}$ 
distilled water was added, and heating constantly. The produced yield was cooled, diluted with distilled water. For tea- leaves and tomato sauce analysis, five-gram samples were weighed accurately, (550 and $175 \mathrm{mg}$ of them, respectively) was taken and follow the same procedure as mentioned above. Taking $10-\mathrm{mL}$ of each aqueous solution for $\mathrm{Al}^{3+}$ ions estimation adjusted at the ideal circumstances of the proposed mode and the providing results are tabulated in Section 3.6.

For $\mathrm{Al}^{3+}$ ion determination in real samples, $0.5 \mathrm{~g}$ of the mashed selected sample of some rocks (Basalt, Rhyolite and Granite) was dissolved in $10 \mathrm{~mL}$ of 20 molars hydrofluoric acid solution under gentle heating condition till dryness. (500 mg of each of them) was transferred into a conical flask, dissolving the residue in $5 \mathrm{~mL}$ of 4 molars sulfuric acid, diluted to $25 \mathrm{~mL}$, then diluted 250 times with distilled water. Adjusting the $\mathrm{pH}$ at 5 using an acetate buffer solution.

In the case of the analysis of standard alloys, weighed accurately the percent content alloy, transferred (250 and $300 \mathrm{mg}$ of copper and zinc-based alloy, respectively) into a conical flask, and dissolved completely in $40 \mathrm{~mL}$ of hydrochloric acid with heating, adding $3 \mathrm{~mL}$ of $30 \% \mathrm{H}_{2} \mathrm{O}_{2}$. The mixture was cooled and filtered and diluted to $500 \mathrm{~mL}$ with distilled $\mathrm{H}_{2} \mathrm{O}$. For each of the alloy solutions, $10 \mathrm{~mL}$ were taken for the estimation of $\mathrm{Al}^{3+}$ ions applying the proposed method at the ideal circumstances. The resulting data are reported in Section 3.6.

\subsection{Membrane Electrode Fabrication}

The fabricated electrode was displayed as published before [67]. It contains a column sensor of Teflon commutable and a form full of a liquid phase sensor " $+\mathrm{Ag} / \mathrm{Ag} \mathrm{Cl}$ " (an internal reference electrode).

The complex, plasticizer and the polyvinylchloride; PVC were grounded, adding tetrahydro furan as a flown solvent. A convenient diameter disk was cut and glued to the flat end of polyvinyl chloride; PVC tubing with Tetrahydrofuran; THF. The form of the sensor was wind with 0.001 molar specific solution of aluminum membrane electrode. The developed electrode was conditioned by soaking for $24 \mathrm{~h}$ in 0.01 molar $\mathrm{Al}^{3+}$ solution and kept for a remnant duration in a similar solution.

\subsection{Working Constituent of Liquid-Electrode Coat}

The cited reagent 2,9-dimethyl-4,11-diphenyl-1,5,8,12-tetraazacyclo tetradeca-1,4,8,11tetraene[DDTCT] is a white powder active membrane component. It dissolved completely in diluent trahydrofuran $(15 \mathrm{~mL})$ and made up with methanol to $100 \mathrm{~mL}$, concentration $=5 \times 10^{-4}$ molar at pH 5.0-8.0. The cited reagent was conditioned as described before [66].

\subsection{Preparation of the Potential Layer}

A precise weight $0.02 \mathrm{~g}$ active constituent [Al(DDTCT)] mixed with $0.35 \mathrm{~g}$ PVC, and $0.63 \mathrm{~g}$ TBP were grounded to provide the suggested electrode's coat. A Teflon electrode with a reference of $\mathrm{Ag} / \mathrm{AgCl}$ was completely wined with the recently conditioned mixture, then transferring to gel by heating at a suitable temperature of $375 \mathrm{~K}$ for $20 \mathrm{~min}$. After cooling, the suggested sensor was conditioned for two hrs., into a $10^{-3}$ molar solution aluminum ion.

\subsection{EMF Measurements}

An Orion 90-02 reference electrode was applied with a mechanical stirrer to provide a veracity of $0.1 \mathrm{mV}$ at the laboratory conditions to measure the EMF of the aluminum electrode regulation. An Orion 90-00-01 solution including 0.05 M sodium chloride, $1.5 \mathrm{M}$ potassium nitrate, $0.55 \mathrm{M}$ potassium chloride, and $40 \%$ formaldehyde one $\mathrm{ml}$ was utilized to complete filling the stabilized bridge of the reference electrode. 


\section{Results}

The analytical validation of our designed aluminum sensor were investigated to estimate its prominence in practical utilities. The selectivity characteristics, detection limit, the observed slope, the restraint time, and dependence of $\mathrm{pH}$ on the electrode potential response were also examined.

\subsection{The Calibration Curve of the Suggested Electrode}

Figure 1 presented the developed aluminum electrode's calibration curve detected in aluminum and its interfering ions of $10^{-7}-10^{-1}$ molar solutions.

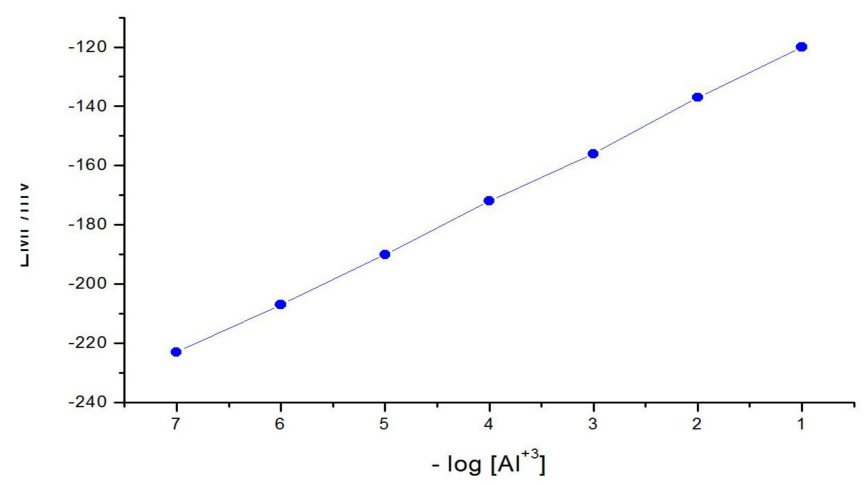

Figure 1. The curve of calibration of the developed $\mathrm{Al}(\mathrm{III})$ electrode over the concentration scope $10^{-7}-10^{-1} \mathrm{M}$.

The aluminum sensor's characteristics slope is $20 \mathrm{mV}$, the limit of detection is $1.6 \times 10^{-7}$ molar and the measuring range is $2.5 \times 10^{-7}-1.5 \times 10^{-1}$ molar. Table 1 summarised the analytical characteristic parameters of the constructed aluminum sensor.

Table 1. Analytical validations of the developed $\mathrm{Al}^{3+}$ electrode matrix membrane.

\begin{tabular}{cc}
\hline Specific Slope $/ \mathrm{mV}$ & 58.00 \\
Intercept $/ \mathrm{mV}$ & $-51.4+0.2$ \\
Limit of detection $/ \mathrm{mol} \mathrm{dm}^{-3}$ & $1.6 \times 10^{-7}$ \\
Measuring range $/ \mathrm{mol} \mathrm{dm}^{-3}$ & $2.5 \times 10^{-7}-1.5 \times 10^{-1}$ \\
Response time $/ \mathrm{s}$ & 12 \\
Lifetime $/ \mathrm{d}$ & 150 \\
$\mathrm{pH}$ range & $5.0-8.0$ \\
\hline
\end{tabular}

\subsection{Selectivity Behavior}

The selectivity behavior of the $\mathrm{Al}^{3+}$ sensor with various interfering ions such as $\mathrm{Cd}, \mathrm{Ni}, \mathrm{Co}, \mathrm{Ca}$, and $\mathrm{Cu}$ with the same concentration of aluminum $10^{-3}$ molar were examined applying the modes of the separate solution or the MP, (matched potential) listed previously [67] applying the equations:

$$
\log \mathrm{K}_{\mathrm{ij}}^{\text {pot }}=\mathrm{E}_{2}-\mathrm{E}_{1} / \mathrm{S}-\left(\mathrm{Z}_{\mathrm{i}} / \mathrm{Zj}-1\right) \log \mathrm{a}_{\mathrm{i}}, \mathrm{K}^{\text {pot }} \mathrm{Al} / \mathrm{M}=\frac{\mathrm{ai}}{\mathrm{ai} \frac{\mathrm{zi}}{\mathrm{zj}}}
$$

By using the separate solution method, at the EMF value of $\mathrm{Al}^{3+}$ ions with the concentration $0.001 \mathrm{M}$ and, the potential $-160 \mathrm{mV}$. For the matched potential mode, the equation is:

$$
\mathrm{K}^{\text {pot }} \mathrm{Al} / \mathrm{M}=\frac{\mathrm{ai}}{\mathrm{ai} \frac{\mathrm{zi}}{\mathrm{zj}}}
$$

The provided results are tabulated in Table 2. 
Table 2. The values of selectivity coefficients $(\mathrm{K})$ of $\mathrm{Al}^{3+}$ electrode.

\begin{tabular}{cccc}
\hline \multicolumn{3}{c}{ Separate Solution Method (SSM) } & Matched Potential Method \\
\hline $\mathbf{K}$ & $\mathbf{E i}=\mathbf{E j}$ & $\mathbf{a i}=\mathbf{a j}$ & $\mathbf{M P M}$ \\
\hline $\mathrm{AlCl}_{3}$ & $0.338+0.0320$ & $0.366+0.010$ & $0.366+0.0200$ \\
$\mathrm{CdCl}_{2}$ & $0.250+0.0060$ & $0.333+0.020$ & $0.295+0.0100$ \\
$\mathrm{NiCl}_{2}$ & $0.074+0.0030$ & $0.162+0.004$ & $0.278+0.0110$ \\
$\mathrm{CoCl}_{2}$ & $0.055+0.0120$ & $0.077+0.001$ & $0.006+0.0010$ \\
$\mathrm{CaCl}_{2}$ & $0.282+0.0070$ & $0.363+0.050$ & $0.312+0.0070$ \\
$\mathrm{CuCl}_{2}$ & $0.017+0.0002$ & $0.078+0.003$ & $0.014+0.0006$ \\
\hline
\end{tabular}

\subsection{Response Time of the Suggested Aluminum Electrode}

For analytical validations, the restraint time of the fabricated selective developed electrode is very important. For dilution adding water (1:1) after injecting the standard concentrated solution, Solutions used for the determination of the restraint time of the suggested tested electrode have the following conditions: $\mathrm{v}_{1}: \mathrm{v}_{2}=1: 20, \mathrm{c}_{1}: \mathrm{c}_{2}=1: 100$, where $\mathrm{v}_{1}$ is the quantitative amount of the sample, and $\mathrm{v}_{2}$ is the standard quantitative amount, $\mathrm{c}_{1}$ is the sample concentration, $c_{2}$, the concentration of the standard. The obtained data are presented in Figure 2. After 12 seconds of adding aluminum the response of the sensor is reproducible. At the instant of injection of the concentrated sample the timer is started, the quick and stable reading of potential reflecting the time required for ending the titration. The ion-selective electrode scopes its balance in a shortened response time (12 s) over the whole linear of the applicable concentration range as shown from Figure 2.

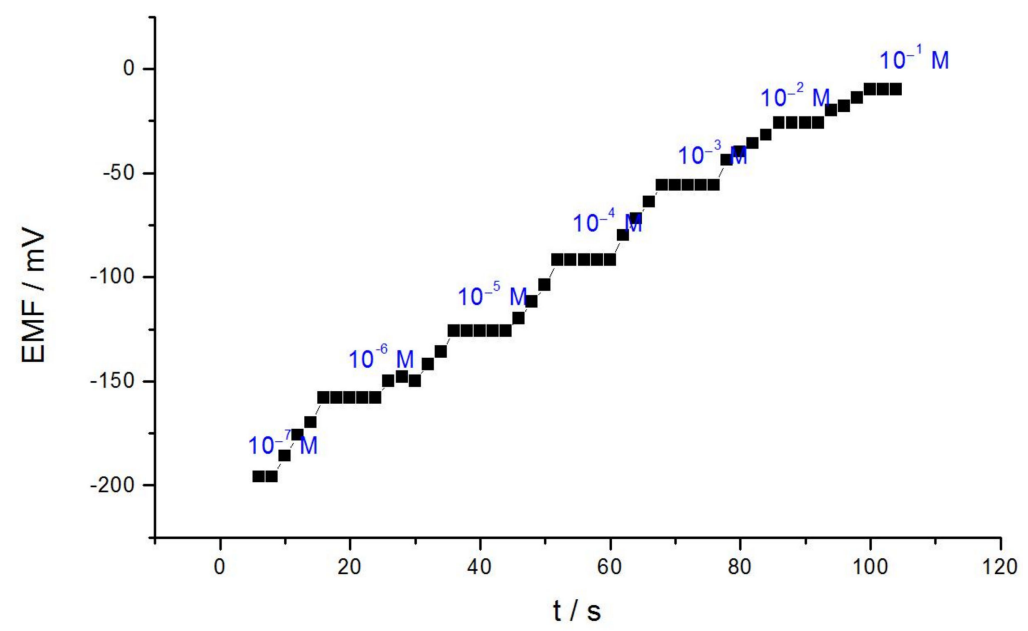

Figure 2. The time of response of $\left[10^{-3} \mathrm{M}\right]$ concentration of proposed aluminum electrode.

\section{4. $\mathrm{pH}$ Influence on the Proposed Electrode Potential}

The influence of the sensor potential on the $\mathrm{pH}$ was investigated by tracking the potential measurements with respect to the chemical property of aluminum salts. Stepwise of sodium hydroxide or hydrochloric acid or were provided to the investigated $0.001 \mathrm{M}$ aluminum ions sample. the $\mathrm{pH}$ was reported after each increment, the ratio of the electromotive force; EMF of the aluminum membrane system/reference electrode was measured after the sensor's restraint was attained. The influence of $\mathrm{pH}$ on the EMF is presented in Figure 3. Below and above this $\mathrm{pH}$ range (5.0-8.0), at higher $\mathrm{pH}$ values, the potential decreases $(-187$ at $\mathrm{pH} 9,-192$ at $\mathrm{pH} 9.5$, and -198 at $\mathrm{pH} 10)$ may be due to the hydrolysis of $\mathrm{Al}^{3+}$ ions or the complex formation is not completing. At lower $\mathrm{pH}$ values, potential increases $(-125$ at $\mathrm{pH} 2.4,-134$ at $\mathrm{pH} 2.7$, and -140 at $\mathrm{pH} 3$ ) attributed to the membrane responses to hydronium. and/ or $\mathrm{Al}(\mathrm{III})$ ions. 


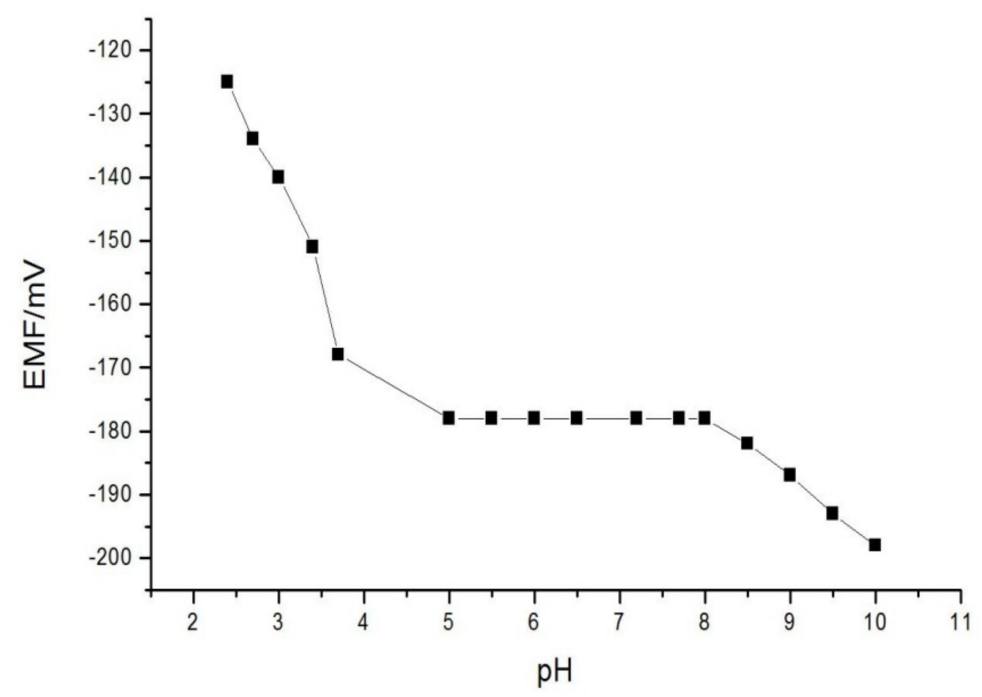

Figure 3. Influence of the developed electrode restraint on the $\mathrm{pH}$ in $\left[10^{-3} \mathrm{M}\right]$ aluminum ion concentration.

\subsection{Duration time of the Aluminum Sensor}

The duration time of the investigated aluminum sensor under studying was tested by measuring the specific slopes of the membrane electrode kept in $4{ }^{\circ} \mathrm{C}$. The regular investigations were completed once a week for 7 months, in recently conditioned solutions in a consistent mode. Stabilized and repeatable signs were obtained through 5 months. It was noticed that a trivial decrease in the sensor slope by $1.0 \mathrm{mV} \mathrm{decade}{ }^{-1}$ from $58.00-57.00 \mathrm{mV} /$ decade and an increment in the limit of detection value. By the end of the time period, the slope of the electrode decreased gradually, whereas the detection limit is increased to become (from 52.34 to $48.16 \mathrm{mV}$ per decade and $3.2 \times 10^{-6}$ to $4.5 \times 10^{-5} \mathrm{M}$, respectively) were observed. This probably arises from the leaching of the electrode constituents. Thus, the long duration time of the sensor is about 5 months, according to the subsistence of the provided results.

\subsection{Determination of Aluminum in Foodstuff, Real Samples, and Standard Alloys}

The dissection of $\mathrm{Al}^{3+}$ ions in foodstuff, real samples, and standard alloys was examined applying the suggested sensor to study its practical utility. The processes of standard additions and that of the calibration curve were applied, the detected data and their analyzed validation are presented in Table 3.

Table 3. Estimation of aluminum in foodstuff, real samples and standard alloys applying the proposed sensor.

\begin{tabular}{|c|c|c|c|c|c|c|c|c|}
\hline \multirow[b]{2}{*}{ Sample } & \multicolumn{4}{|c|}{ Calibration Curve Method } & \multicolumn{4}{|c|}{ Standard Addition Method } \\
\hline & $\begin{array}{c}\text { Sample } \\
\text { Information } \\
\mathrm{mg} / \mathrm{Kg}\end{array}$ & $\begin{array}{c}\mathrm{Al}^{3+} \\
\text { Found } \\
\mathrm{mg} / \mathrm{Kg}\end{array}$ & $\begin{array}{l}\text { Relative } \\
\text { Error \% }\end{array}$ & $\begin{array}{l}\mathrm{V} \\
\%\end{array}$ & $\begin{array}{l}\text { Sample In- } \\
\text { formation } \\
\mathrm{mg} / \mathrm{Kg}\end{array}$ & $\begin{array}{c}\mathrm{Al}^{3+} \\
\text { Found } \\
\mathrm{mg} / \mathrm{Kg}\end{array}$ & $\begin{array}{l}\text { Relative } \\
\text { Error \% }\end{array}$ & $\begin{array}{l}\mathrm{V} \\
\%\end{array}$ \\
\hline Bread & 460 & 460.65 & 0.14 & 0.08 & 460 & 462.75 & 0.60 & 0.15 \\
\hline Flour & 150 & 151.45 & 0.97 & 0.05 & 150 & 152.86 & 1.91 & 0.12 \\
\hline Rice & 750 & 751.55 & 0.21 & 0.23 & 750 & 752.89 & 0.39 & 0.25 \\
\hline Tea-Leaves & 550 & 551.86 & 0.34 & 0.12 & 550 & 552.95 & 0.54 & 0.16 \\
\hline Tomato Sauce & 175 & 176.76 & 1.00 & 0.26 & 175 & 177.54 & 1.45 & 0.16 \\
\hline Chocolate & 400 & 401.85 & 0.46 & 0.35 & 400 & 402.75 & 0.69 & 0.28 \\
\hline Granite & 500 & 501.65 & 0.33 & 0.11 & 500 & 502.15 & 0.43 & 0.51 \\
\hline Basalt & 500 & 501.75 & 0.35 & 0.13 & 500 & 502.65 & 0,53 & 0.26 \\
\hline Rhyolite & 500 & 501.85 & 0.37 & 0.26 & 500 & 502.76 & 0.55 & 0.22 \\
\hline $\begin{array}{l}\text { Copper-based } \\
\text { alloy NBS164 }\end{array}$ & 250 & 251.95 & 0.78 & 0.37 & 250 & 252.75 & 1.10 & 0.23 \\
\hline $\begin{array}{c}\text { Zinc-based alloy } \\
\text { NIST94C }\end{array}$ & 300 & 301.85 & 0.62 & 0.27 & 300 & 302.75 & 0.92 & 0.26 \\
\hline
\end{tabular}




\section{Discussion}

The characteristic Nernstian slope is a quite paramount parameter to evaluate eclectic sensors that are specifically applied in the analysis. The optimum value of the Nernstian slope is $59.1 / \mathrm{n}$ (mV/decade), where $(\mathrm{n})$ is the valency [68]. This indicates that for $\mathrm{Al}^{3+}$ electrode with the $\mathrm{n}$ value $=3$ is $19.7 \mathrm{mV} /$ decade. The value of the specific Nernstian parameter this work was $19.33 \mathrm{mV} /$ decade, indicates an increment in the molarity of $10^{-1} \mathrm{M}$ solutions under-test, the potential alteration of $19.33 \mathrm{mV} /$ decade. This proves that the $\mathrm{Al}^{3+}$ developed electrode is still workable for the dissection of $\mathrm{Al}^{3+}$ application, because the acceptable applicable value of the specific Nernstian slope is $19.7 \mathrm{mV}$.

In this work, various cations were tested as foreign interfering ions. The values of selectivity coefficients presented in Table 2 indicated that the developed aluminum ion electrode is strongly eclectic to aluminum(III) safely in the existence of $\mathrm{Co}, \mathrm{Ca}, \mathrm{Cu}, \mathrm{Cd}$, and $\mathrm{Ni}$. As shown from the obtained results, none of the investigated interfering cations had a noticed effect on the reaction of the potentiometric measurements of the membrane sensor towards aluminum ions. Obviously, for all applied different cations, the selectivity coefficients values are smaller, providing they would not safely hinder the work of the suggested $\mathrm{Al}^{3+}$ electrode. The surprise of the noticed great selectivity of the sensor towards $\mathrm{Al}^{3+}$ ions in the existence of other tested cations is attributed to the greatest ability of the carrier molecules for aluminum ions.

Also, as summarized in (Table 3) that the calibration curve and the standard additions methods were utilized. The analysis of the resulting data showed that the calibration curve method is more preferable in the estimation of $\mathrm{Al}^{3+}$ while the method of standard additions is less preferred, the noticed error is about $1.91 \%$, and $1.0 \%$ in the two ways, respectively, which is attributed to the repeatability, veracity, and reproducibility of the style.

The results provided by the fabricated $\mathrm{Al}^{3+}$ electrode were analyzed, and compared with the previously published ion-selective sensor. The data regarded in Table 4 compare between some of the important parameters of the quantitative estimation of $\mathrm{Al}^{3+}$ ions applying various selective sensors published before to indicate that the developed sensor performs acceptable good finding and be utilized for $\mathrm{Al}^{3+}$ ions estimation in foodstuff, real samples and standard alloys. As presented in Table 4 the developed sensor exhibits a comparable linear concentration range $\left(2.5 \times 10^{-7}-4.5 \times 10^{-1} \mathrm{M}\right)$ which is more valuable than the other previously reported $\mathrm{Al}^{3+}$ selective sensors [2,7,42-50]. It has a longer life span (150 days ) in comparison to the previously reported sensors, those have low detection limits, the lowest one is that introduced in our work $\left(1.6 \times 10^{-7}\right)$ even with the nearest linear concentration range. Further, the developed sensor has numerous advantages in comparison to others sensors, it is easier to construct, it is low cost. Thus, it can be reliable to state that our proposed electrode is acceptable to use with other sensors for $\mathrm{Al}^{3+}$ ions estimation.

Table 4. Some interesting analytical validations of Al [DDTCT] in comparison with previously listed ion selective membrane sensors for aluminum determination.

\begin{tabular}{|c|c|c|c|c|c|}
\hline Reference & $\begin{array}{l}\text { Specific Slope } \\
(\mathrm{mV})\end{array}$ & $\begin{array}{c}\text { Linearity } \\
\text { Concentration } \\
\text { Range (M) }\end{array}$ & Duration Time & $\begin{array}{c}\text { Detection } \\
\text { Limit } \\
\text { (M) }\end{array}$ & $\begin{array}{l}\text { Working } \\
\text { pH Range }\end{array}$ \\
\hline This work Results & 58.0 & $2.5 \times 10^{-7}-4.5 \times 10^{-1}$ & 5 months & $1.6 \times 10^{-7}$ & $5.0-8.0$ \\
\hline [2] & $19.6 \pm 0.4$ & $1.0 \times 10^{-6}-1.0 \times 10^{-1}$ & $>3$ months & $6.3 \times 10^{-7}$ & $3.0-6.0$ \\
\hline [7] & $20 \pm 0.2$ & $1.6 \times 10^{-6}-1.0 \times 10^{-1}$ & 3 months & $6.0 \times 10^{-7}$ & $3.0-8.5$ \\
\hline [42] & $19.3 \pm 0.8$ & $5.0 \times 10^{-6}-1.0 \times 10^{-2}$ & $>2$ months & $2.5 \times 10^{-6}$ & $3.5-5.0$ \\
\hline [43] & 19.5 & $1.0 \times 10^{-5}-1.0 \times 10^{-1}$ & 1 month & $3.2 \times 10^{-6}$ & $2.25-3.25$ \\
\hline [44] & 29.5 & $1.0 \times 10^{-5}-1.0$ & 2 months & $1.0 \times 10^{-6}$ & - \\
\hline$[45]$ & $18.5 \pm 0.7$ & $1.0 \times 10^{-6}-1.0 \times 10^{-2}$ & 2 months & $1.3 \times 10^{-7}$ & $0.5-3.0$ \\
\hline [46] & $19.7 \pm 0.1$ & $3.2 \times 10^{-5}-1.0 \times 10^{-1}$ & 2 months & $3.2 \times 10^{-7}$ & $3.5-5.0$ \\
\hline [47] & $19.8 \pm 0.4$ & $1.0 \times 10^{-6}-1.0 \times 10^{-1}$ & $>4$ months & $4.6 \times 10^{-7}$ & $2.0-6.0$ \\
\hline [48] & $19.0 \pm 0.4$ & $1.0 \times 10^{-6}-1.0 \times 10^{-1}$ & 2 months & $5.5 \times 10^{-7}$ & $4.0-8.0$ \\
\hline [49] & $21.3 \pm 0.18$ & $7.0 \times 10^{-6}-1.0 \times 10^{-2}$ & - & $6.0 \times 10^{-6}$ & - \\
\hline [50] & $19.6 \pm 0.3$ & $1.0 \times 10^{-7}-1.0 \times 10^{-2}$ & 11 weeks & $5.0 \times 10^{-8}$ & - \\
\hline
\end{tabular}


No detected interference was attained from the constituents that existed in the investigated samples. The curve of calibration presented an excellent response to the linearity range of concentrations. Several methods introduce valuable results compared to the real values and there is no noticeable variations were shown for either precision or accuracy.

\section{Conclusions}

The constructed aluminum selective sensor was developed. The proposed membrane sensor has many excellent analytical characteristics: relatively short response time, long duration-lifetime, and the Nernstian slope. Tables 1 and 2 displayed the analytical characteristics of our investigated new sensor.

The constructed sensor was applied for $\mathrm{Al}^{3+}$ ions estimation in food stuffs, real samples, and standard alloys which utilized in common. The method of calibration curve and that of the standard additions were utilized. The analyzed results have confirmed that the calibration curve method is better and more preferable than the standard additions method in the aluminum estimation. However, the noticeable error is not bigger than $1 \%$ which is attributed to the repeatability and reproducibility of the applied method. The method described in Table 4 for the proposed sensor was sufficiently precise, and accurate in comparison with the other described that are utilized in common for aluminum ions estimation in foodstuff products, environmental real samples, and standard alloys.

The proposed ion-selective electrode was applied for $\mathrm{Al}^{3+}$ ion estimation in the selected samples of foodstuff, real, and standard alloy that utilized in common. The methods of standard additions and that of the calibration were utilized. The analyzed results showed that the calibration curve way is better in the deduction of foodstuff, real, and standard alloy samples than the way of standard additions which is less preferred. Therefore, due to the reproducibility and repeatability of the proposed method, the error is no bigger than $2 \%$.

Thus, the results exhibited excellent quality which is attributed to the good luck with the selection of samples applying the developed selective proposed sensor. The time consumed through the estimation is tested alone with no considerable influence on the veracity, reproducibility, and exactitude of the obtained data.

Author Contributions: Formal analysis, A.Y.E.; supervision, S.K.; resources, A.Y.E.; Software, A.Y.E.; writing-original draft preparation, S.K.; writing-review and editing, S.K. All authors have read and agreed to the published version of the manuscript.

Funding: This research received no external funding.

Institutional Review Board Statement: Not applicable.

Informed Consent Statement: Not applicable.

Data Availability Statement: The data that support the findings of this study are available on request from the corresponding author.

Acknowledgments: This work was carried out using the facilities and materials in Taif University Researches Sup-porting Project number (TURSP-2020/32), Taif University, Taif, Saudi Arabia.

Conflicts of Interest: The authors declare no conflict of interest.

\section{References}

1. Ma, Y.J.; Yuan, R.; Chai, Y.Q.; Liu, X.L. Medical Treatment Toxicity associated with exposure to aluminum. Mater. Sci. Eng. 2010, 30, 209-214. [CrossRef]

2. Arvand, M.; Asadollahzadeh, S.A. Ion-selective electrode for aluminum determination in pharmaceutical substances, tea leaves and water samples. Talanta 2008, 75, 1046-1054. [CrossRef] [PubMed]

3. Good, P.F.; Olanow, C.W.; Perl, D.P. Check Blood levels of aluminum in patients with kidney failure. Brain Res. 1992, 593, 343-349. [CrossRef]

4. Parkinson, I.S.; Ward, M.K. Toxicity of Aluminum in humans. J. Clin. Pathol. 1981, 34, 1285-1291. [CrossRef]

5. King, S.W.; Savory, J.; Willis, M.R. Effect of aluminum deficiency in biological life. Crit. Rev. Clin. Lab. Sci. 1981, 13, 1-5. 
6. Abel-Ghany, M.; Ei-Sebae, A.K.; Shalloway, D. Aluminum as a valuable factor in pathological diseases. J. Biol. Chem. 1976, 268, 976-982.

7. Yari, A.; Darvishi, L.; Shamsipur, M. Al(III)-selective electrode based on newly synthesized xanthone derivative as neutral ionophore. Anal. Chim. Acta 2006, 555, 329-335. [CrossRef]

8. Kalayci, S.; Somer, G.; Ekmekci, G. Preparation and application of a new glucose sensor based on iodide ion selective electrode. Talanta 2005, 65, 87-91. [CrossRef] [PubMed]

9. Karimian, F.; Rounaghi, G.H.; Arbab-Zavar, M.H. Connstruction of a PVC based 15-crown-5 electrochemical sensor for Ag(I) cation. Chin. Chem. Lett. 2014, 25, 809-814. [CrossRef]

10. Mitrovic, B.; Milacic, R. Determination of aluminum in biological samples by graphite furnace atomic absorption technique. Sci. Total Environ. 2002, 258, 183-190.

11. Narin, I.; Tuzen, M.; Soylak, M. Aluminium determination in environmental samples by graphite furnace atomic absorption spectrometry after solid phase extraction on Amberlite XAD-1180/pyrocatechol violet chelating resin. Talanta 2004, 63, 411-418. [CrossRef]

12. Nguyen, K.L.; Lewis, D.M.; Jolly, M. Determination of soluble aluminium concentration in alkaline humic water using atomic absorption spectrophotometry. J. Water Res. 2004, 38, 4039-4045. [CrossRef]

13. De Amorim, F.R.; Bof, C.; Franco, M.B.; da Silva, J.B.B.; Nascentes, C.C. Atomic Absorption Spectrometric Determination of aluminum in different samples. Microchem. J. 2006, 82, 168-175. [CrossRef]

14. Sun, M. Determination of trace-aluminum in human serum album by graphite furnace atomic absorption spectrometry. Chin. J. Pharm. Anal. 2007, 27, 113-116.

15. Wu, J.W. Atomic Absorption Spectrometric determination of aluminum in real samples. J. Shanxi Med. Univ. 2005, 36, 518-525.

16. Sun, M.; Wu, Q. Determination of ultra-trace aluminum in human albumin by cloud point extraction and graphite furnace atomic absorption spectrometry. J. Hazard. Mater. 2010, 176, 901-908. [CrossRef] [PubMed]

17. Zhu, X.; Bao, L.; Guo, R.; Wu, J. Determination of aluminum(III) in water samples in a micro-emulsion system by spectrofluorimetry. Anal. Chim. Acta 2004, 523, 43-48. [CrossRef]

18. Yamada, E.; Hiwada, T.; Inaba, T.; Tokukura, M.; Fuse, Y. Speciation of aluminum in soil extracts using cation and anion exchangers followed by a flow-injection system with fluorescence detection. Anal. Sci. 2002, 18, 785-791. [CrossRef] [PubMed]

19. Takeuchi, T.; Inoue, S.; Yamamoto, M.; Tsuji, M.; Miwa, T. Fluorimetric determination of magnesium and aluminum via complexation with oxine in HPLC. J. Chromatogr. A 2001, 910, 373-376. [CrossRef]

20. Chen, J.-L.; Liu, C.-Y. Chelating resin sorption followed by supercritical fluid extraction and liquid chromatographic determination of aluminum in liquid samples. Anal. Chim. Acta 2003, 494, 125-132. [CrossRef]

21. Lian, H.; Kang, Y.; Yasin, A.; Bi, S.; Shao, D.; Chen, Y.; Dai, L.; Tian, L. Determination of Aluminum in enviormental and biological samples by reversed-phase HPLC. J. Chromatogr. A 2003, 993, 179-185. [CrossRef]

22. Lian, H.; Kang, Y.; Bi, S.; Arkin, Y.; Shao, D.; Li, D.; Chen, Y.; Dai, L.; Gan, N.; Tian, L. Direct determination of trace aluminum with quercetin by reversed-phase high performance liquid chromatography. Talanta 2004, 62, 43-50. [CrossRef]

23. Soylak, M.; Sahin, U.; Ülgen, A.; Elci, L.; Dogan, M. Determination of Aluminum at trace level in water samples by visible absorption spectroscopy with a laser Diode. Anal. Sci. 1997, 13, 287-289. [CrossRef]

24. Froes, R.E.S.; Borges Neto, W.; Naveira, R.L.P.; Silva, N.C.; Nascentes, C.C.; Silva, J.B.B. Exploratory analysis and inductively coupled plasma optical emission spectrometry applies in the determination of metals in soft drinks. Microchem. J. 2009, 92, 68-72. [CrossRef]

25. Ricknagel, S.; Rosixk, U.; Bratter, P. Determination of rare earth elements in mineral waters by ICP-AES. J. Anal. Atom. Spectrom. 1994, 9, 1293-1300.

26. Bantan, T.; Milacic, R.; Pihlar, B. Possibilities for speciation of Al-citrate and other negatively charged Al complexes by anionexchange FPLC-ICP-AES. Talanta 1998, 46, 227-235. [CrossRef]

27. Harigaya, K.; Kuwahara, Y.; Nishi, H. Determination of aluminum in large volume parenteral drug products by ICP-MP with a dynamic reaction cell. Chem. Pharm. Bull. 2008, 56, 475-479. [CrossRef]

28. Bocca, B.; Alimonti, A.; Petruccia, F.; Violante, N.; Sancesario, G.; Forte, G.; Senofonte, O. Quantification of the trace elements by sector field ICP-Ms in urine, serum, blood and cerebrospinal fluid. Spectrochim. Acta B 2004, 59, 559-566. [CrossRef]

29. Chu, Q.; Li, X.H.; Ding, Y.; Zhang, L.; Fang, J.D. Determination of some metal catios using ICP-MP technique. Res. Environ. Eng. 2007, 21, 68-74.

30. Xia, L.; Hu, B.; Jiang, Z.; Wu, Y.L.; Li, L.; Chen, R. 8-Hydroxyquinoline-chloroform single drop micro-extraction and electrothermal vaporization ICP-Ms for the determination of aluminum in natural waters and drinks. J. Anal. Atom. Spectrom. 2005, 20, 441-446. [CrossRef]

31. Hassan, N.I.; Ahmad, M. Spectrophotometric determination of aluminum based on ion-associate complex with new reagent. Sins Malays. 2007, 36, 189-194.

32. Kamino, S.; Yamaguchi, T.; Mori, T.; Miyamoto, M.; Kusumi, Y.; Fujita, Y. Spectrophotometric determination of aluminum with m-carboxyphenyl fluorene, a novel chemical probe, and its application. Anal. Sci. 2005, 21, 1549-1552. [CrossRef]

33. Bahrama, M.; Madrakianb, T.; Bozorgzadehb, T.; Afkhamib, A. Micelle-mediated extraction for simultaneous spectrophotometric determination of aluminum and beryllium using mean centering of ratio spectra. Talanta 2007, 72, 408-414. [CrossRef] [PubMed] 
34. Shokrollahi, M.; Ghaedi; Niband, M.S.; Rajabi, H.R. Selective and sensitive spectrophotometric method for determination of sub-micro-molar amounts of aluminum ion. J. Hazard. Mater. 2008, 151, 642-648. [CrossRef] [PubMed]

35. Niazi, A.; Zolgharnein, J.; Davoodabadi, M.R. New analytical spectrophotometric method for the determination of aluminum. Ann. Chim. 2007, 97, 1181-1188. [CrossRef]

36. Zheng, H.L.; Xiong, M.G.; Gong, Y.K.; Peng, D.J. Spectrophotometric determination of aluminum (III) in real samples. Spectrochim. Acta A Mol. Biomol. Spectrosc. 2007, 66, 1243-1250. [CrossRef] [PubMed]

37. Agnihotri, N.K.; Singh, H.B.; Sharma, R.L.; Singh, V.K. Simultaneous determination of beryllium and aluminum in mixtures using derivative spectrophotometry. Talanta 1993, 40, 415-423. [CrossRef]

38. Azhari, S.J.; Amin, S.A. High sensitive and Selective spectrophotometric determination of aluminum. Anal. Lett. 2007, 40, 2959-2964. [CrossRef]

39. Ahmed, M.J.; Hoque, M.R.; Shahed, A.S.M.; Khan, H.; Bhattacharjee, S.C. New Spectrophotometric method for the determination of aluminum ions. Eurasian J. Anal. Chem. 2010, 5, 1-7.

40. Huseyinli, A.A.; Alieva, R.; Haciyevaa, S.; Guray, T. Spectrophotometric determination of aluminium and indium with 2,2' $3,4-$ tetrahydroxy-3',5'-disulphoazobenzene. J. Hazard. Mater. 2009, 163, 1001-1007. [CrossRef]

41. Buratti, M.; Valla, C.; Pellegrino, O.; Rubino, F.M.; Colombi, A. Determination of aluminium ions in pharmaceutical formulations. Anal. Biochem. 2006, 353, 63-72. [CrossRef] [PubMed]

42. Abbaspour, A.; Esmaeilbeig, A.R.; Jarrahpour, A.A.; Khajeh, B.; Kia, R. Aluminium(III) selective electrode based on a newly synthesized tetradentate Schiff base. Talanta 2002, 58, 397-403. [CrossRef]

43. Saleh, M.B.; Hassan, S.M.; Abdel Gaber, A.A.; Kream, N.A. Novel potentiometric membrane sensor for selective determination of aluminum(III) ions. Anal. Chim. Acta 2001, 434, 247-253. [CrossRef]

44. Babenikov, V.; Bykova, L.; Evsevleeva, L. Aluminum selective electrode. J. Anal Chem. 2005, 60, 866-867.

45. Mousavi, M.F.; Arvand, M.; Zanjanchi, M.A. Ion-selective membrane sensor for the determination of aluminum. Electroanalysis 2001, 13, 1125-1133. [CrossRef]

46. Gupta, V.K.; Jain, A.K.; Maheshwari, G. Aluminum(III) selective potentiometric sensor based on morin in poly(vinyl chloride) matrix. Talanta 2007, 72, 1469-1573. [CrossRef]

47. Arvand, M.; Kermanian, M. Potentiometric determination of aluminum in Foods, Pharmaceuticals, and Alloys by modefied carbon paste electrode. Food Anal. Method 2013, 6, 578-586. [CrossRef]

48. Masoomeh, E.; Gholam, H.; Rounaghi, M.H. Construction of a new selective aluminum (III) cation selective electrode. J. Braz. Chem. Soc. 2015, 26, 963-969.

49. El-Badry, M. Modified carbon paste electrode for potentiometric determination of aluminum ion in spiked real water sample. Russ. J. Electrochem. 2016, 52, 754-761.

50. Saber, A.L.; Abd El Shafey, I.A. Novel ionophore for aluminum ion sensors: Synthesis and analytical characterization. LEEE Sens. J. 2016, 16, 5867-5874. [CrossRef]

51. Atty, S.A.; Sedik, G.A.; Morsy, F.A.; Naguib, D.M.; Zaazaa, H.E. A novel sensor aluminum silicate modified carbon paste electrode for determination of anti-depressant dothiepin $\mathrm{HCl}$ in pharmaceutical formulation and biological fluids. Microchem. J. 2019, 148, 725-734. [CrossRef]

52. Youssef, A.F.; Abd Dayiem, M.; Shehab, O.R. Use of dicloxacillin Al(III) Complex as a modifier for determination of Al(III) ion in real samples. Electroanalysis 2020, 32, 2902-2912. [CrossRef]

53. Yuana, W.; Wana, M.; Wua, X. Prediction of forming limit curves for 2021 aluminum alloys. Procedia Eng. 2017, $207,544-549$. [CrossRef]

54. Sedwick, V.; Leal, A.; Turner, D.; Kanu, A.B. Quantitative determination of aluminum in deodorant brands. J. Chem. Educ. 2018, 95, 451-455. [CrossRef]

55. Eckert, P.J.; Prashanth, K.; Wu, M.; Kaban, I.; Scudino, L.S. A review of particulate-reinforced aluminum matrix composites fabricated by selective laser melting. Trans. Nonferrous Met. Soc. China 2020, 30, 2001-2009.

56. Renedo, O.D.; Navarro-Cunado, A.M.; Romany, E.V.; Asuncion, M.; Lomillo, A. Determination of aluminum using different techniques based on the Al(III)-morin complex. Talanta 2018, 196, 131-136. [CrossRef] [PubMed]

57. Hafez, E.M.; El Sheikh, R.; Fathallah, M.; Saygal, A.A.; Gouda, A.A. An environment-friendly supramolecular solvent-based liquid-phase micro-extraction method for determination of aluminum in water and acid digested food samples prior to spectrophotometry. Microchem. J. 2019, 150, 104-110. [CrossRef]

58. Braas, S.; Lostak, T.; Pappert, E.; Flook, J.; Schram, J. On-line electrolytic dissolution for soluble aluminum determination in high-silicon steel/electrical sheet by ED-FIA-ICP-OES. Talanta 2018, 189, 489-493. [CrossRef] [PubMed]

59. Abdul Haleem, P.; Tuzen, M.; Kazi, T.G. Deep eutectic solvent based advance micro-extraction method for determination of aluminum in water and food samples: Multivariate study. Talanta 2018, 178, 588-593.

60. Gupta, V.K.; Singh, L.P. Encyclopedia of Sensors, 5; Grimes, C.A., Dickey, B., Eds.; American Scientific Publishers: Los Angeles, CA, USA, 2006; p. 133.

61. Abe, I.; Horiba, T.; Abe, Y.; Hida, K.; Matsuyama, T.; Yasuno, S.; Komaba, S. Investigation and improvement of metallic aluminum as alloying electrode in non-aqueous Li Cell. J. Electrochem. Soc. 2020, 167, 513-518. [CrossRef]

62. Sekularac, G.; Milosev, I. Electrochemical behavior and Self-Sealing ability of zirconium conversion coating applied on aluminum Alloy 3005 in $0.5 \mathrm{M} \mathrm{NaCl}$ Solution. J. Electrochem. Soc. 2020, 167, 150-159. [CrossRef] 
63. Renganathan, V.; Ramachandran, B.; Shen-Ming, C.H.; Sakthivel, K.; Muthumariappan, A. Bifunctional bimetallic heterojunction material based on $\mathrm{Al}_{2} \mathrm{O}_{3} / \mathrm{ZnO}$ micro flowers for electrochemical sensing and catalysis. Ecotoxicol. Environm. Saf. 2019, 176, 250-257. [CrossRef] [PubMed]

64. Basha, V.S.; Chowdary, P.G.; Renuka, M. Non-extractive spectrophotometric determination of cobalt (II) using 2- acetylthiophene isonico tinoylhydrazone in environmental and pharmaceutical samples. J. Pharma Drug Res. 2019, 2, $102-109$.

65. Sulaiman, S.T.; Hamoudi, T.A. Spectrophotometric determination of cobalt(II) with mordant blue 9-application to vitamin B12 (injections and powder). Raf. J. Sci. 2018, 27, 93-100.

66. Khalil, S. Ion-selective electrode for gallium determination in nickel alloy, fly-ash and biological samples. Anal. Chim. Acta 2006, 562, 204-209.

67. Khalil, S.; El Sharnouby, M. Construction of a highly selective membrane sensor for the determination of cobalt (II) ions. Chemosensors 2021, 9, 86. [CrossRef]

68. Panggabean, A.S. Preparation and characterization ion selective electrode Cd(II) based on chitosan in PVC membrane. Indones. J. Chem. 2011, 11, 285-292. [CrossRef] 